\title{
Industrial Sustainability and the Circular Economy as Counterparts to the Self- Referral Structure of Natural Law: Part II - A Global Case Study
}

\author{
Lee Fergusson $^{1 *}$ \\ ${ }^{1}$ Maharishi Vedic Research Institute, Australia \\ *Corresponding author: Lee Fergusson: lee@maharishivedicresearch.org
}

\section{OPEN ACCESS}

Citation: Fergusson L. (2017) Industrial Sustainability and the Circular Economy as Counterparts to the Self-Referral Structure of Natural Law: Part II - A Global Case Study. Open Science Journal 2(4)

Received: $6^{\text {th }}$ August 2017

Accepted: $7^{\text {th }}$ November 2017

Published: $5^{\text {th }}$ December 2017

Copyright:@ 2016 This is an open access article under the terms of the Creative Commons Attribution License, which permits unrestricted use, distribution, and reproduction in any medium, provided the original author and source are credited.

Funding: The author(s) received no specific funding for this work

Competing Interests: The author have declared that no competing interests exists.

\begin{abstract}
:
Part I of this two-part series of research papers identified the theoretical foundations of industrial sustainability and circular economy in the structure of Natural Law, as explained by Maharishi Vedic Science. Part I showed that all levels of a manifest hierarchy are governed by self-referral and selfinteracting feedback loops, and maintained that the circular economic model represents a counterpart to the self-referral mechanics of Natural Law and is therefore more in accord with Natural Law than the standard linear 'take, make, dispose'economic model, which is unsustainable due to its attitude to and management of energy and other resource portfolios, waste and end-of-life products.

This Part II explores the self-referral structure of Natural Law in the context of one of the world's largest industrial hazardous wastes: alumina refinery residue or 'red mud'. The paper examines how this solid waste residue, which is generated at a rate of more than 120 million tonnes each year, can: a) be incorporated into a sustainable, circular economic model in order to reduce waste and improve productivity; and b) be reused or repurposed as either a feedstock to other industrial and municipal processes, such as concrete and cementitious product manufacture, agriculture and mine site rehabilitation, or, if such reuse applications generate other forms of waste, how these, too, can enter further cascading circular economies through beneficial reuse.
\end{abstract}


I propose that a long-term economic and environmental benefit from alumina refinery residue can be liberated when its reuse is based on the principles of self-referral and self-interacting feedback loops as described by Maharishi Vedic Science, and suggest that the deep-rooted commercial, human and environmental risks posed by this industrial waste stream can be minimized or even eliminated through a circular approach to waste management, thereby leading to a more sustainable economic future for the world.

Keywords: Industrial sustainability, Circular economy, Alumina refinery residue, Red mud, Natural Law, Maharishi Vedic Science

\section{Introduction}

The present paper is predicated on the theories and practices of Maharishi Vedic Science as explained by Maharishi Mahesh Yogi, founder of Maharishi Vedic University in Europe, Maharishi University of Management in the United States, and Maharishi Mahesh Yogi Vedic Vishwavidyalaya University in India. Maharishi's contributions to the modern academic disciplines include detailed analyses of the nature and scope of physics (spanning investigations into Superstring Field Theory, quantum cosmology, and cosmology to explain the "evolution of the material universe" [Maharishi, 1996a, pp. 584-585 and pp. 635637]), chemistry, mathematics, and physiology (Maharishi, 1996a, pp. 154-422), as well as comprehensive inquiries into education (Maharishi, 1996b), health sciences (Maharishi, 1996c), administration (Maharishi 1998), military science (Maharishi, 1996a), the arts and architecture (Fergusson \& Bonshek, 2015), and global economics (Maharishi Global Development Fund, 1998).

From the perspectives of both Maharishi Vedic Science and modern science, observed physical creationis governed by a hierarchy of unseen laws of nature, which are organised and unfold sequentially from a unified,unseen, non-material source of intelligenceand order to an ever-increasingly complex, diversified and expanding material universe. The unified source of creation is described severally as "Natural Law", the "home of all the laws of nature", Dharma (धर्म, or "that which upholds the universe"), and Purushottama (पुरुषोत्तम, being the "absolute ruler of the ever-expanding universe") in Vedic Science (Maharishi, 1995, pp. 30, 36 and 116), and as the "unified field" in physics (e.g., Heisenberg, 1984) and chemistry (e.g., Gatti \& Macchi, 2012). According to Maharishi (1986, 1995), these laws of nature, which compose and guide the fundamental force fields and elementary particles of human and natural life, arise spontaneously from within the unbroken, unbounded intelligence of nature's functioning through a series of continuous self-referral and self-interacting feedback loops.

In Maharishi Vedic Science, the unmanifest level of creation is described as a field of pure, unbounded consciousness, a field of pure intelligence responsible for human, natural and cosmic life. "The silent level of consciousness", Maharishi 
explains (1995, p. 273), "is a field of all possibilities where the total potential of the organizing power of Natural Law is always fully awake, fully alert. It is the silent, omnipresent level of Natural Law that spontaneously governs the universe". Heaton (2016, p. 126) has pointed out that some contemporary theorists have apparently arrived at a similar conclusion, citing Erich Jantsch who described a "conscious universe which is self-organising" and David Bohm who views the universe as "an unbroken whole in which information about the whole...is enfolded in every part". Maharishi (1995, p. 235) maintains that this field of pure consciousness "is an eternal continuum. Its self-referral nature is expressed in the structure of a circle. A circle can be big or small. It can be smaller than the smallest or bigger than the biggest. As long as it is a circle it represents a continuum". For this reason, Maharishi (1995) refers to Natural Law, which is the governing principle of pure consciousness, as the "self-sufficient source of order in nature" (p. 78) and points out that it is "self-administering" (p. $3)$.

In Part I of this two-part series of research papers (Fergusson, in review), I explained how pure consciousness referred to itself in an eternally continuous and circular way, and how its internal conceptualised properties spontaneously and simultaneously interact with themselves and with their unified state to propel creation forward, always governed by Natural Law. Part I also introduced Maharishi's explanation of how this process resulted in not only the outward selfprojection of the laws of nature into the universe, but how these phenomena 'return' via further self-referral feedback loops to complete the circle of what he calls the "source, course and goal of gaining knowledge" (Maharishi, 1994, p. 45).This principle of Natural Law having a circular structure at all levels of a manifest hierarchy, operating according to a continuous self-referral mechanics, is akin to the principles and motivations driving the circular economic model, in which societies aim to conserve natural resources, reduce, recycle and reuse waste, and be generally "smarter" when using assets, there by ultimately avoiding what some theorists argue will be "self-extinction" (Tietenberg \& Lewis, 2016).Part I therefore proposed that a circular economy represents a counter part or comparable structure to Natural Law because it has a "structural similarity and functional uniformity" to the self-referral mechanics of Natural Law (Maharishi, 1995, pp. 239-240).

Stahel (2016, p. 436) has identified two main types of industrial economic model. The first is the linear economy which "flows like a river", turning natural resources into base materials and products for sale through a series of valueadding steps. According to Lacy and Rutqvist (2015), the linear model has served companies well for 250 years, but has become increasingly impractical. The model was largely instigated during the Industrial Revolution and is most closely aligned with modern capitalism rather than with traditional societies and economies. It is said that the linear economic model, because it rapaciously uses diminishing natural resources, is unsustainable (e.g., Tietenberg \& Lewis, 2016)because it will result in a projected natural resource shortfall between global supply and demand of 8.0 billion tonnes by 2030 (Lacy \& Rutqvist, 2015). Part I therefore argued that this model is unsustainable and does not reflect the selfreferral properties of Natural Law.

Figure 1(A) shows how extracted resources, such as waste, minerals and energy, are transferred to manufacturing processes which generate a variety of 
waste streams in the linear model; these wastes are most often disposed or discharged untreated to the environment, while base materials and products are distributed to society. At the end of their useful life, these products are incinerated, disposed or discarded to the environment, most often to landfill, but sometimes into rivers, the sea or oceans, or into the atmosphere. By definition the linear model is unsustainable because it does not recognise the finite limits of natural resources nor does it fully account for the adverse impacts its waste streams have on the environment (e.g., the adverse effects of $\mathrm{CO}_{2}, \mathrm{NOx}, \mathrm{CH}_{4}$ on global climate, or waste plastic on the world's oceans and marine life [e.g., Jambeck et al., 2015]), wastes which are often left for "someone else to deal with" (Lacy \& Rutqvist, 2015, Executive Summary).

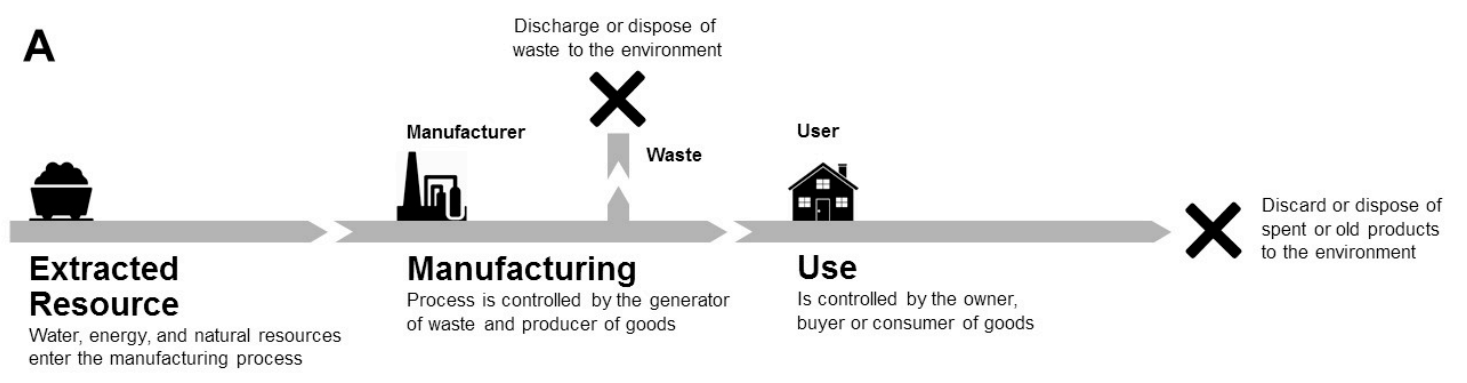

B

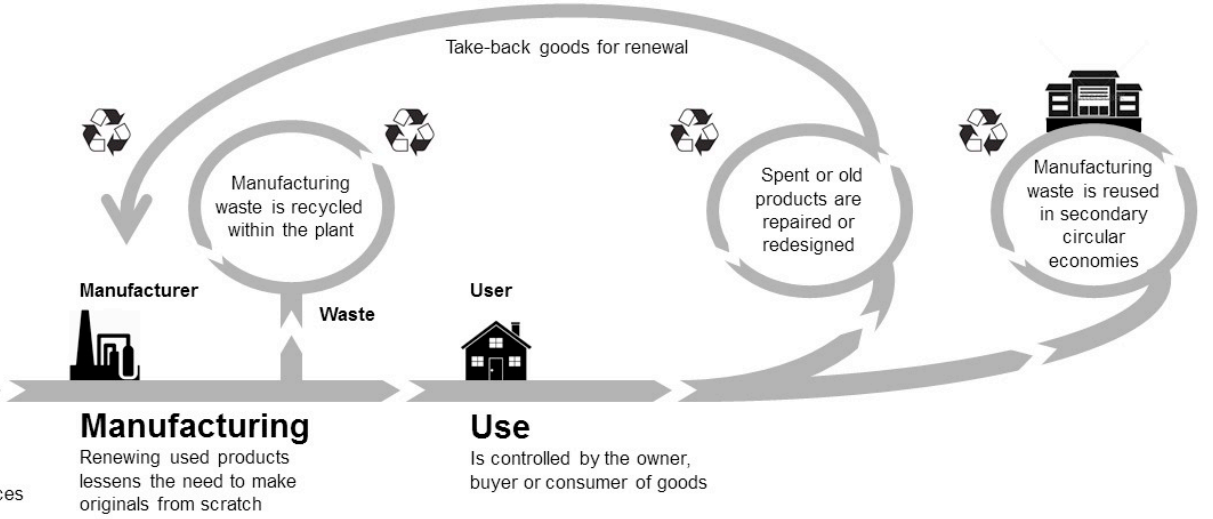

Figure 1. Basic steps in the linear 'take-make-dispose' model (A) and basic steps in the circular economy (B).

Figure 1(B) presents another type of economic model (Ghiselliniet al., 2016). The circular economy (CE) is "like a lake", according to Stahel (2016, p. 436), because its parts interact in a mutually dependent and symbiotic manner. CE has evolved to help companies reduce their dependence on diminishing and increasingly costly natural resources while generating revenue from the so-called 'waste-to-resource' mentality (Jiang et al., 2012). According to Stahel (2016, p. 436), "reprocessing of goods and materials generates jobs and saves energy while reducing resource consumption and waste. Cleaning a glass bottle and using it again is faster and cheaper than recycling the glass or making a new bottle from minerals". Rather than being dumped, waste and spent or old products in this model are repaired or redesigned for later downstream beneficial reuse in secondary CEs (what some theorists call "industrial symbiosis" [e.g., Chertow, 2007]), or can be returned to circuit for reuse by the original manufacturer or others. 
Figure 1(B) also shows that manufacturing waste can in some cases be recycled as part of the manufacturing process, spent or old products can be repaired or redesigned by users or can be returned to the manufacturer for renewal, and manufacturing waste can be re-routed to secondary circular economies to be reused in a variety of downstream applications. Of importance in CEs are the closing of end-of-pipe processes; Webster (2017, p. 17) describes these as ever tighter "inner loops", which "preserve more energy and other value". Some theorists have therefore contrasted the "cradle-to-grave" mentality of the past with the "cradle-to-cradle" mentality of the future, predicting a " $\$ 4.5$ trillion reward for turning current waste into wealth by 2030" (e.g., Lacy \& Rutqvist, 2015, Executive Summary). Where waste and spent or old products were discarded in the take-make-dispose linear economy shown in Figure 1(A), potentially resulting in the downstream pollution of receiving environments and systems, in $\mathrm{CE}$ the open-endedness of these processes are closed and refer only to themselves, as shown in Figure 1(B).

Mathews and Tan (2011, p. 436) have thus identified three levels of CE as applied to what they call "closed-loop initiatives". The first relates to the practice when confined to a single enterprise or small group of enterprises in order to "enhance energy and resource efficiencies" for the purposes of "cleaner production". The second level of CE relates to the practice when applied to clusters of enterprises with common supply chains, whereby:

a group of co-located firms (e.g., in an eco-industrial park [EIP]) share certain streams of resources and energy and so enhance their collective energy and resource efficiency. This is one of the key concerns of industrial ecology, described as industrial symbiosis-along with other concerns, such as identifying energy and material flows that could be described as industrial metabolism. In either case, them odel is the cycles of nature, which keep replenishing the basic requirements for life, such as water, carbon, and nitrogen. When co-located in an industrial area and planned as such, the initiatives are sometimes known as 'eco-industrial parks' (Mathews 8 Tan, 2011, p. 436).

The third level of CE, as identified by Mathews and Tan (2011), relates to an entire city or municipality which interconnects its processes and recycling efforts by incentivising economic and administrative initiatives (and penalising enterprises which do not interconnect or recycle), such as those found throughout China (e.g., Zhang et al., 2009), including (in the context of the present study) initiatives involving smelters (Mathews \& Tan, 2011, p. 438). In these ways, CE theory embraces the principles of a continuum, a circle without end, as opposed to a river with a beginning (i.e., inputs, such as natural resources) and an end (i.e., outputs, such as products and waste by-products) (Pollard et al., 2016), and thereby mimics and reflects the self-referral feedback loops of Natural Law.

It is also important to note that in a sense similar to Maharishi's description of how Natural Law operates in continuous and progressively elaborate selfreferral feedback loops of 'evolution' (e.g., Maharishi, 1996a), so too the circular nature of $\mathrm{CE}$ does not mean it merely 'goes around' in a purposeless circle but is 'spiralled' to progress and advance the interests of stakeholders, society and the environment. For these reasons, CE theory is said to be a more sustainable 
industrial approach than the traditional take-make-dispose model (e.g., Solow, 2014).

From this brief overview of CE theory, three further topics of relevance to industrial sustainability can be identified: 1) reduction or elimination of waste as a result of applying CE models; 2) reduction of inefficiencies and improved efficiencies as a result of applying CE models; and 3) increase of productivity and improvements in production controls as a result of applying $\mathrm{CE}$ models to industry.

One of the cornerstones of CE theory is its attempt to reduce or eliminate industrial and urban waste, a comprehensive analysis of which has been provided by Tisserant et al. (2017) for solid waste streams such as ash and clinker, construction debris, metals, glass and plastics. In the context of urban biocycles, the Ellen MacArthur Foundation (2017) has, for example, pointed out that 13 billion tonnes of biomass flow annually through urban economies as food, energy and materials, and there is, as a consequence, significant opportunity to reduce waste volumes and capture value from the organic flows of urban environments. Such value, derived from urban solid waste streams (which constitute about 1.3 billion tonnes per year globally, with a $100 \%$ increase projected by 2025) and wastewater, may be realised in the form of energy, nutrients (mostly in the form of phosphorus $[\mathrm{P}]$, nitrogen $[\mathrm{N}]$ and potassium $[\mathrm{K}]$ ) and materials. Industries which contribute to, and can thus derive benefit from, such initiatives include agriculture, forestry, fisheries, food processing, manufacturing and biotechnology. Together these industries generate a global value of nearly $\$ 13$ trillion and make up about $13 \%$ of the global gross domestic product (Ellen MacArthur Foundation, 2017, p. 8), and many now see the advantage to "closing the nutrient loop". In theory, recovery of $\mathrm{P}, \mathrm{N}$ and $\mathrm{K}$ from these various waste streams could account for up to 2.7 times the volume of nutrients currently required for global fertiliser production. According to the Ellen MacArthur Foundation,

a recent study on residual organic waste in Amsterdam, the Netherlands, high value processing could lead to added value of $€ 150$ million, as well as 900,000 tonnes of material savings and a reduction of 600,000 tonnes in $\mathrm{CO}_{2}$ emissions annually for the city. These benefits can be generated using biorefineries, waste separation and return logistics, cascading organic flows and nutrient recovery. (2017, p. 8)

Moreover, in contrast to the linear economic model, CE theory argues that significant efficiencies (in other words 'reductions') in both natural resource utilisation and waste generation, particularly those associated with large populations and fast-growing economies, can be gained. For example, according to Mathews and Tan, and consistent with the governments of Japan and Germany,

China's national leadership has clearly understood that continued development in the traditional linear manner, starting with resources taken from nature at one end and proceeding through production processes to the creation of wastes disposed in nature at the other end, is simply no longer feasible. It is destructive to the point of ruin, at both ends, and it is costly to both secure 
fresh resources all the time and lose resources in the form of waste: It is, in other words, both economically and ecologically inefficient. (2011, p. 437)

The reduction of nutrient inefficiencies through $\mathrm{CE}$, specifically $\mathrm{P}$, has been a focus. For example, Withers et al. (2015, p. S193) explain the inefficient use of P in the food chain and why it is a threat to the global aquatic environment, leading to recommendations for a five-part "strategic framework" for Pstewardship which considers the realignment of $\mathrm{P}$ inputs, the reduction of $\mathrm{P}$ losses to the environment, the recycling of $\mathrm{P}$ in bio-sources, the recovery of $\mathrm{P}$ from wastes, and the redefinition of $\mathrm{P}$ in food systems. The authors claim that such a framework will "help identify and deliver a range of integrated, costeffective, and feasible technological innovations to improve $\mathrm{P}$ use efficiency in society and reduce [Europe's] dependence on P imports" (p. S193). Mathews and Tan (2011, p. 438) have also reported on the significant CE efficiency gains in energy and materials consumption as documented throughout China, which they claim are consistent with "improvements in ecological modernisation", and Tukker (2014) has shown the sustainability relationship between cost- and materials-efficiency and the prolongation of a product's service life, including the reuse and repurposing of a product's parts after the end-of-product-life.

A third important factor when considering the benefits of $\mathrm{CE}$ to a sustainable future is its role in productivity gains, a topic of related research since the 1990s (e.g., in biodiversity and agricultural research [Tillman et al., 1996]). Indeed, it is for the specific benefit of increased productivity that $\mathrm{CE}$ has been formally embraced by the leadership of China (Geng et al., 2009; Yuan et al., 2006), the country in which a significant amount of research on this factor has been carried out. For example, Su et al. (2013, p. 216) have identified industrial symbiosis of $\mathrm{CE}$ leads to collective benefits which "come from both economic and environmental aspects. Economically, firms' agglomeration brings pools of common production factors such as labour, capital, and energy which may decrease factor prices or raise productivity", and Zhu et al. (2010) have investigated whether corporate performance is associated with types of $\mathrm{CE}$ businesses in China.

Specific concerns about energy consumption also form a cornerstone of CE theory (e.g., George et al., 2015). For example, Tonelli et al. (2013) have pointed out that

since 1900, the rate of global consumption of fossil fuel has increased by a factor of 50. These dynamics pose unparalleled challenges for existing industrial systems and infrastructure devoted to production, distribution, and consumption. By 2050, in fact, the global industrial system is expected to double its output using 50\% of current resources and generating $20 \%$ of current $\mathrm{CO}_{2}$. Thus, the industrial system will be central to the world economy through the coming century, and if a resilient economy is really desired, this will only be feasible through a very different 'low-carbon, resource-efficient' approach. (pp. 144-145)

This view of energy is largely consistent with Maharishi's (1991, p. 157) own perspective when he said that "creating pollution-free industry and a noise-free, pollution-free healthy atmosphere through [the] profuse use of solar energy- 
creating a post-industrial era free from the stress and strain of the industrial age" is a laudable aim when applying his Vedic Science. He explains, from a more fundamental viewpoint, that the creative process of Natural Law

owes its emergence and draws its vitality from that self-referral performance of pure intelligence. This self-referral state of pure consciousness, while remaining uninvolved with the creative process in nature, is an infinitely dynamic, inexhaustible source of energy and creativity. On that basis the whole of creation goes on perpetually in its infinite variety, multiplying itself all the time. (Maharishi, 1986, p. 30)

Part I of this series outlined the motivations and historical context of CE as they relate to industrial sustainability (Mathews \& Tan, 2011), and this author and his colleagues have explored Maharishi Vedic Science and its relation to sustainability science (Fergusson et al., 2016) and human capability (Kettle et al., 2017). Specifically, we have examined the relationship of Vedic Science to the Jain tradition of ecological awareness (Fergusson et al., 2017a) and to the environmental stewardship of Aboriginal and Torres Strait Islanders of Australia and Māori of New Zealand (Fergusson et al., 2017b), and we have considered the threat of global climate change and the contribution of Maharishi Vedic Science to understanding and addressing it (Wells et al., 2017). Part II now proposes a $\mathrm{CE}$ model as it applies to alumina refinery residue (ARR), one of the world's most problematic hazardous industrial solid wastes, and suggests that it too can mimic the dynamics of self-referral Natural Law.

As a point of orientation, I use the term "industrial sustainability" to mean an industrial process, program, system or practice that can be maintained or kept going without depleting itself or damaging its surroundings, however I also recognise the term has many meanings, and can be defined differently in different contexts. For example, Ackom et al. (2010, p. 2261) use it to mean "the production of goods [and services] to satisfy the society's present requirements without jeopardizing future generations' ability to meet their need for similar goods and services. This definition was later expanded by researchers at the University of Cambridge to include the conceptualization and design phases of manufacturing".

\section{Industrial context}

Alumina $\left(\mathrm{Al}_{2} \mathrm{O}_{3}\right)$ is produced by refining bauxite ore, which is stripped from large open-cut mines; after smelting, alumina is the feedstock in production of aluminium. About 259 million tonnes of bauxite is mined annually throughout the world from a global reserve of between 55 and 75 billion tonnes (Bray, 2014, p. 27). The most common method of digesting alumina from bauxite is the Bayer process. In this process, insoluble alumina is produced when bauxite is digested using sodium hydroxide (i.e., caustic soda, $\mathrm{NaOH}$ ) at a temperature between 100$240^{\circ} \mathrm{C}$ and pressure between 1-6 atm. The waste by-product generated by this process is known colloquially as "red mud", but is referred to as "alumina refinery residue" by the alumina industry (Rai et al., 2012). For everyone tonne of bauxite processed, between 300 and $500 \mathrm{~kg}$ of alumina and 500 and $700 \mathrm{~kg}$ of 
caustic ARR are generated, with alumina being routed to a smelter for primary casting into aluminium products, including ingots, billots, slabs and t-bars, and ARR discharged untreated into long-term, on-site impoundments (or sometimes disposed to the sea [such as the Mediterranean] or ocean utilising submarine tailings disposal [STD], according to the European Aluminium Association [2013, p. 19]), as shown in Figure 2(A). In the Bayer process, both heat and $\mathrm{NaOH}$ are recycled to the digestion circuit.

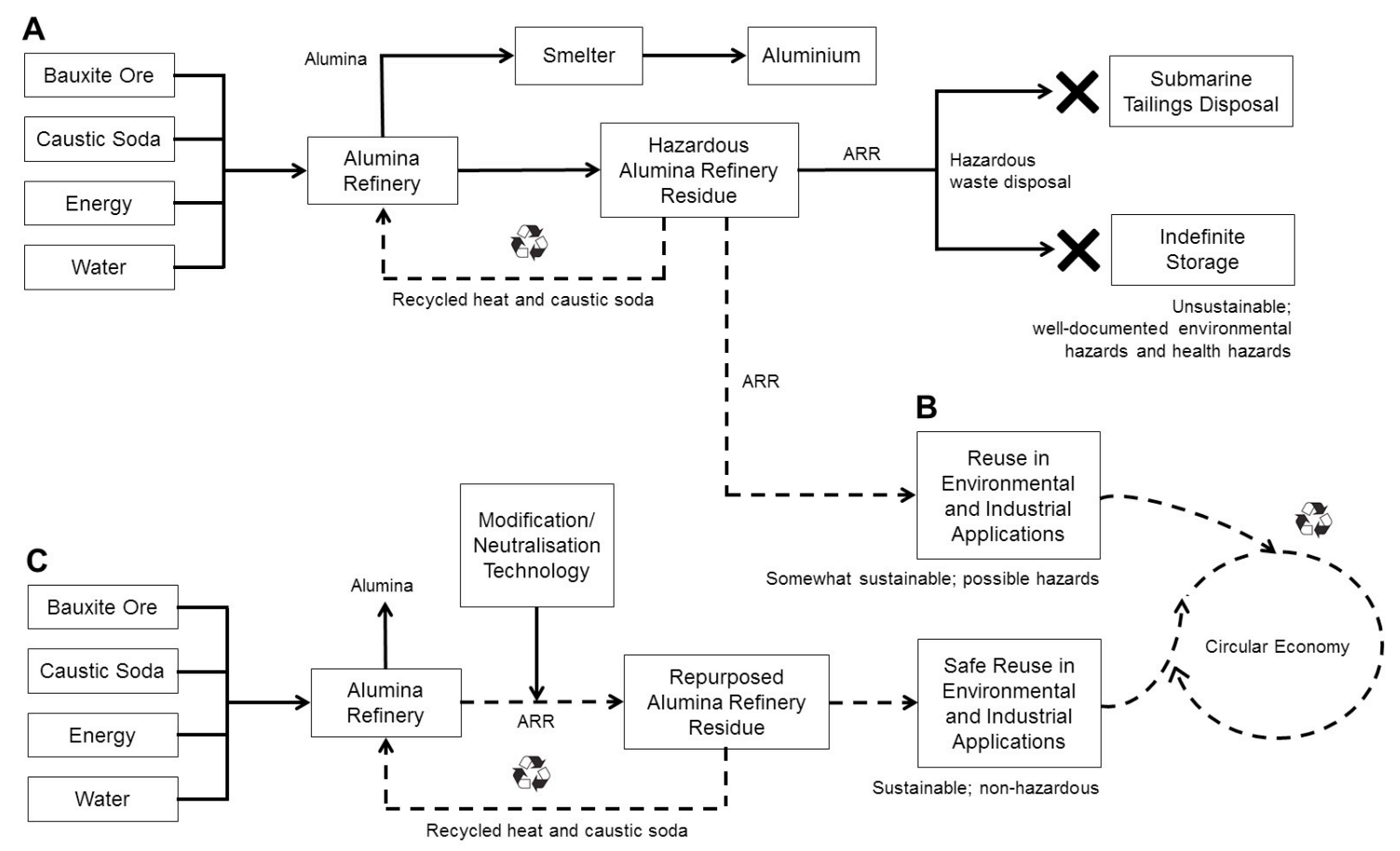

Figure 2. Standard process flow in the production of alumina and hazardous ARR (A), and its potential reuse (B) and sustainable reuse after repurposing (C).

When discharged from the refinery, ARR is highly alkaline (typically around $5,000 \mathrm{mg} / \mathrm{kg}$ [i.e., parts per million] of total alkalinity, but sometimes as high as $30,000 \mathrm{mg} / \mathrm{kg}$ or $3 \%$ alkalinity) with a $\mathrm{pH}>12.0$. ARR is classified as a hazardous (Brunori, et al., 2005) and possibly toxic (Mays et al., 2016) industrial waste under most national and international jurisdictions and conventions, such as the Basel Convention (i.e., classification \#B2110), due to its dangerously high caustic properties. ARR can severely burn skin on contact, and is an irritant to eyes, nose and throat, among other damaging characteristics (e.g., Harris, 2016, pp. 26-28).

The generation of large amounts of ARR presents a significant disposal and operational problem for the alumina industry. To put this statement into context, consider that at least 120 million tonnes of ARR are generated each year by refineries in Australia, Brazil, China, France, India, Romania, Russia and elsewhere (Chuan-Sheng \& Dong-Yan, 2012), with projections of $140 \mathrm{mt}$ by 2018, according to Probert (2014). As one of the world's largest industrial waste byproducts, with about three billion tonnes currently stockpiled in impoundments around the world (Power, et al., 2011) and up to four billion tonnes projected for stockpile or disposal by 2018 (Fiscor, 2013), the issue of safely storing, monitoring and managing hazardous ARR and its potential human, 
environmental and social impacts are non-trivial worldwide industrial and social challenges. Consider, for example, the October 2010 Hungary disaster during which ten people died (Mayes et al., 2016) and life in a neighbouring river was entirely 'extinguished' as a result of a one million tonne ARR spill, to put this conclusion into context (BBC News, 2010).

Among the main stumbling blocks associated with the management of ARR are its physical and chemical properties. Untreated ARR is composed of iron (25$35 \%$ ), aluminium (10-20\%), sodium (3-10\%), titanium (5-10\%), silica (5-20\%) and calcium $(5-10 \%)$ in oxide, hydroxide and/or oxy-hydroxide states. ARR is composed of a complex cocktail of exotic metals and minerals, including hematite $\left(\mathrm{Fe}_{2} \mathrm{O}_{3}\right)$, beohmite $(\boldsymbol{r}$-AlOOH$)$, gibbsite $\left(\mathrm{Al}[\mathrm{OH}]_{3}\right)$, sodalite $\left(\mathrm{Na}_{4} \mathrm{Al}_{3} \mathrm{Si}_{3} \mathrm{O}_{12} \mathrm{Cl}\right)$, anatase $\left(\mathrm{TiO}_{2}\right)$, aragonite $\left(\mathrm{CaCo}_{3}\right)$, brucite $\left(\mathrm{Mg}[\mathrm{OH}]_{2}\right)$, diaspore $\left(\Re_{5}-\mathrm{Al}_{2} \mathrm{O}_{3} \cdot \mathrm{H}_{2} \mathrm{O}\right)$, ferrihydrite $\left(\mathrm{Fe}_{5} \mathrm{O}_{7}[\mathrm{OH}] .4 \mathrm{H}_{2} \mathrm{O}\right)$, gypsum $\left(\mathrm{CaSO}_{4} \cdot 2 \mathrm{H}_{2} \mathrm{O}\right)$, hydrocalumite $\left(\mathrm{Ca}_{2} \mathrm{Al}[\mathrm{OH}]_{7} \cdot 3 \mathrm{H}_{2} \mathrm{O}\right)$, hydrotalcite $\left(\mathrm{Mg}_{6} \mathrm{Al}_{2} \mathrm{CO}_{3}[\mathrm{OH}]_{16} \cdot 4 \mathrm{H}_{2} \mathrm{O}\right)$ and paraaluminohydrocalcite $\left(\mathrm{CaAl}_{2}\left[\mathrm{CO}_{3}\right]_{2}[\mathrm{OH}]_{4} \cdot 3 \mathrm{H}_{2} \mathrm{O}\right)$, many of which contribute to its elevated causticity and potential to burn and corrode. ARR can also contain heavy metals and metalloids, including arsenic (As), chromium ( $\mathrm{Cr}$ ), gallium (Ga) and vanadium (V), and may even contain thorium (Th) and uranium (U). From this chemical analysis, it becomes obvious that ARR has potentially dangerous properties while also harbouring latent and untapped 'value' of interest to CEs.

Figure 2(B) shows how untreated ARR can be (and has been at a rate of about $2.0 \mathrm{mt}$ per year) reused in environmental and industrial applications, including agriculture, concrete, geopolymers and ceramics (e.g., Klauber et al., 2009), but some of ARR's inherently hazardous properties carry over into these applications, potentially contaminating downstream receiving environments, as well as the animals, plants and humans who live in them. Therefore, reuse of ARR is discouraged in most jurisdictions throughout the world.

Alumina refinery residue can, however, be modified to reduce its hazardous properties by repurposing it with innovative technologies, thereby opening the way to unlocking and liberating its latent value and reusing it in a broad range of sustainable environmental and industrial applications, as shown in Figures 2(C) and 6. In this way, ARR can safely enter a circular economy.

\section{Alumina refinery residue and the circular economy}

A significant body of research associated with ARR and its sustainable reuse has been conducted in the last 20 years, however little of it relates to CE. For example, a series of "roadmaps" have been developed by the bauxite, alumina and aluminium industries (Aluminium Association, 2000, 2001, 2003; AMIRA International, 2006; Energetics Incorporated, 1996; European Aluminium Association, 2013; International Aluminium Institute, 2010a; Power, Gräfe \& Klauber, 2009) and these have been used to guide research, development and priority goals.

Industry roadmaps have identified policy areas which focus on either industry goals, benchmarks and challenges oron areas of research and development. The key goals, benchmarks and challenges indicate refineries should: 1) be self- 
sufficient in water; 2) minimise the discharge of dust, gaseous emissions, volatile organic compounds, alkali solutions, and other real or perceived risks to the environment and human health; 3) reduce their energy consumption and seek alternate sources of energy; 4) reduce the impact of scale on operations, thereby reducing costs and improve equipment efficiencies; 5) improve liquor efficiencies; and 6) achieve greater flexibility in digesting a range of different bauxite ores, thereby improving alumina quality. The key areas of research and development include: 1) acceleration of alumina precipitation rates; 2) improved control strategies; 3) improved bauxite beneficiation methods; 4) improved removal of Bayer liquor impurities; 5) reductions in caustic consumption; and 6) improved heat recovery.

The roadmaps also speak generally about managing "bauxite residue in such a way as to promote/encourage [its] use as a product and a resource for other industries and for all remaining residue to be stored in an environmentally friendly form" (International Alumina Institute, 2010b, p. 7) but typically do not explain how this is to be achieved. This limitation is partly due to the fact that roadmaps were developed in the early part of the century and approaches to designing and implementing sustainability programs were still emerging (for example as described by Wells, 2013), but it is also due to an inherent industriocentric view of ARR in which the interests of refineries outweigh the interests of the wider community, economy or natural environment. It is also reasonable to point out roadmaps attempt inclusivity, in that they refer to the involvement of industry, academics and industry associations in the 'sustainable' management of ARR, and alumina refineries do acknowledge the growing impact of environmental and social issues on their industry, however their focus is on alumina as a commodity not on ARR as a potential beneficial reuse raw material and as a consequence they tend to miss out on the richness of a complete and comprehensive framework for developing a sustainable future for the industry as realised through $\mathrm{CE}$.

Figure 3 therefore presents a plausible CE model for ARR, fashioned on the general schema of Stahel (2016, p. 436) and the bio-economic framework of the Ellen MacArthur Foundation (2017, p. 17). The model shows the extracted resources of bauxite, energy, water and $\mathrm{NaOH}$, which are used in the Bayer process, entering the economic cycle. In this process, most of the heat and $\mathrm{NaOH}$ are recycled and powdered alumina is re-directed to a smelter for further valueadded production and thereby cascaded into a secondary circular economy of aluminium recovery (Schmitz, 2006). Rather than discharging ARR to long-term storage or disposing it as an STD as would normally be the case in the linear economic model, ARR can be redirected to users who, with innovative research and development, have invented ways to liberate the embedded value of ARR by repurposing, reclaiming or reusing the treated solid 'waste' (now a 'resource') in agricultural applications, such as soil conditioning, concrete and cementitious production cycles, and mine site rehabilitation.

In order to create a sustainable future for ARR using the CE model based on the principles of self-referral, a more detailed framework of stakeholders and their relations based on several ideational inputs has been posited elsewhere by this author (Fergusson, 2014a, 2015a) and is presented in Figures 4 and 5. The framework assumes long-term and systemic information exchanges and effective 
industrial, municipal, commercial and governmental handshaking, and involves an understanding and embrace of what have been called 'reverse logistics'.

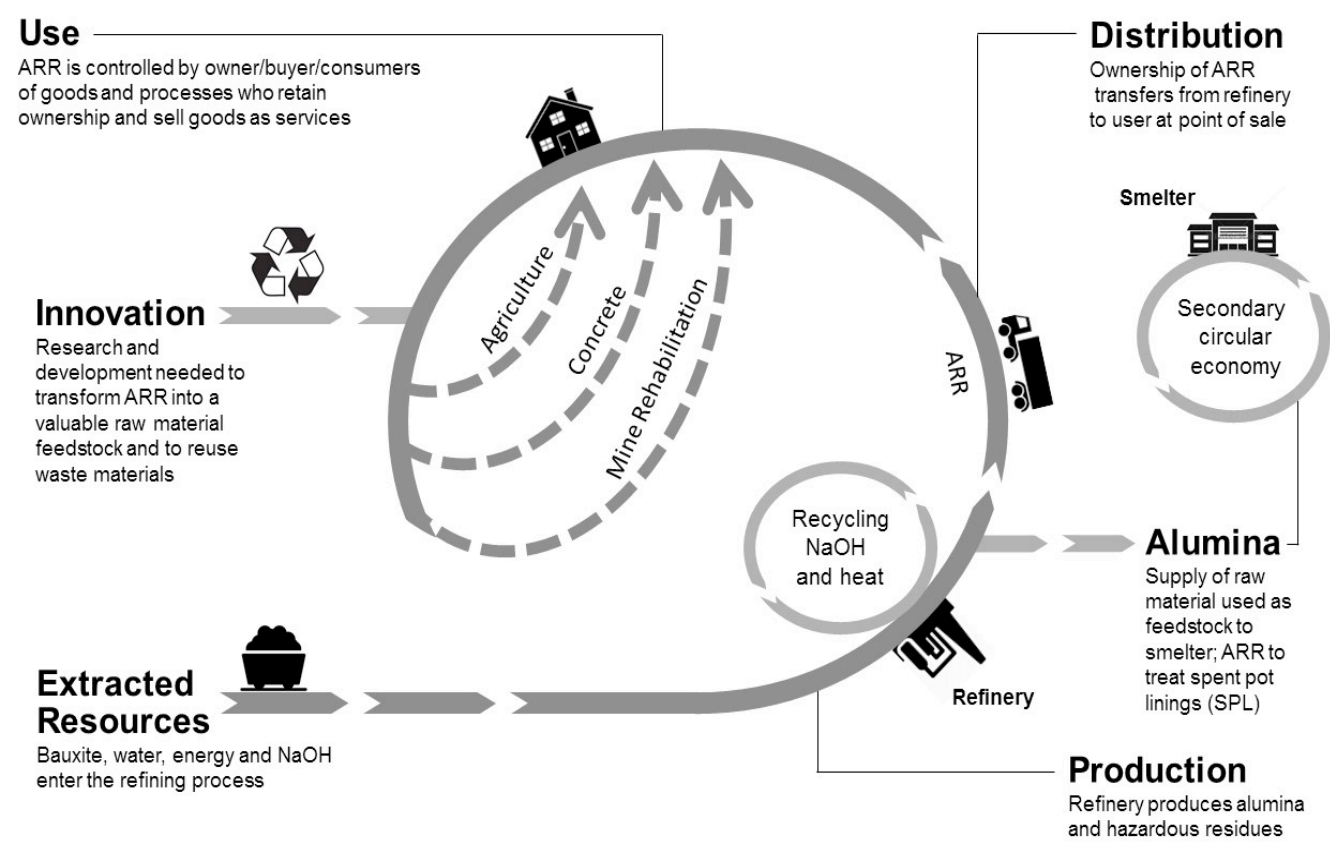

Figure 3. Schematic representation of a CE using alumina refinery residue (modified by the author from Stahel, 2016, p. 436).

The nine stakeholders to the imagined ARR circular economy, each of whom contribute to and benefit from the model, are in Figure 4: Stakeholder [A] the alumina refinery, which plays a central role as supplier of ARR; Stakeholder [B] government agencies; Stakeholder [C] technology solution and service providers; Stakeholder [D] owners and/or managers of contaminated sites, waste producers, and operators of companies which can benefit from the reuse of ARR; and in Figure 5: Stakeholder [E] socially responsible investors; Stakeholder $[\mathrm{F}]$ the media, including print, digital and broadcast media, and marketing and public relations companies; Stakeholder $[\mathrm{G}]$ the scientific research community; Stakeholder $[\mathrm{H}]$ consultants, contractors and industry associations, including civil engineers, environmental consultants and auditors, transportation companies and analytical laboratories; and Stakeholder [I] the general public.

Everything in the model is predicated on ARR being supplied to the circular economy by an alumina refinery [A] (top left of Figure 4), which benefits the refinery by reducing long-term ARR management and monitoring liabilities and costs, potential remediation of their own contaminated site(s), including revegetation of ARR impoundments, increased kudos within industry, government and society, and social goodwill. Contributions from government agencies [B] include licensing and approval of environmental projects, funding for projects through government grants and remediation funds, public relations capabilities, data and statistics, compliance monitoring, and project sign-offs, with governments benefiting from reduced long-term liabilities (i.e., governments inherit the environmental legacy of ARR dumps on closure of the refinery) and thereby potentially reusable and valuable land, an better public relations and perception of government by society, and increased kudos. 


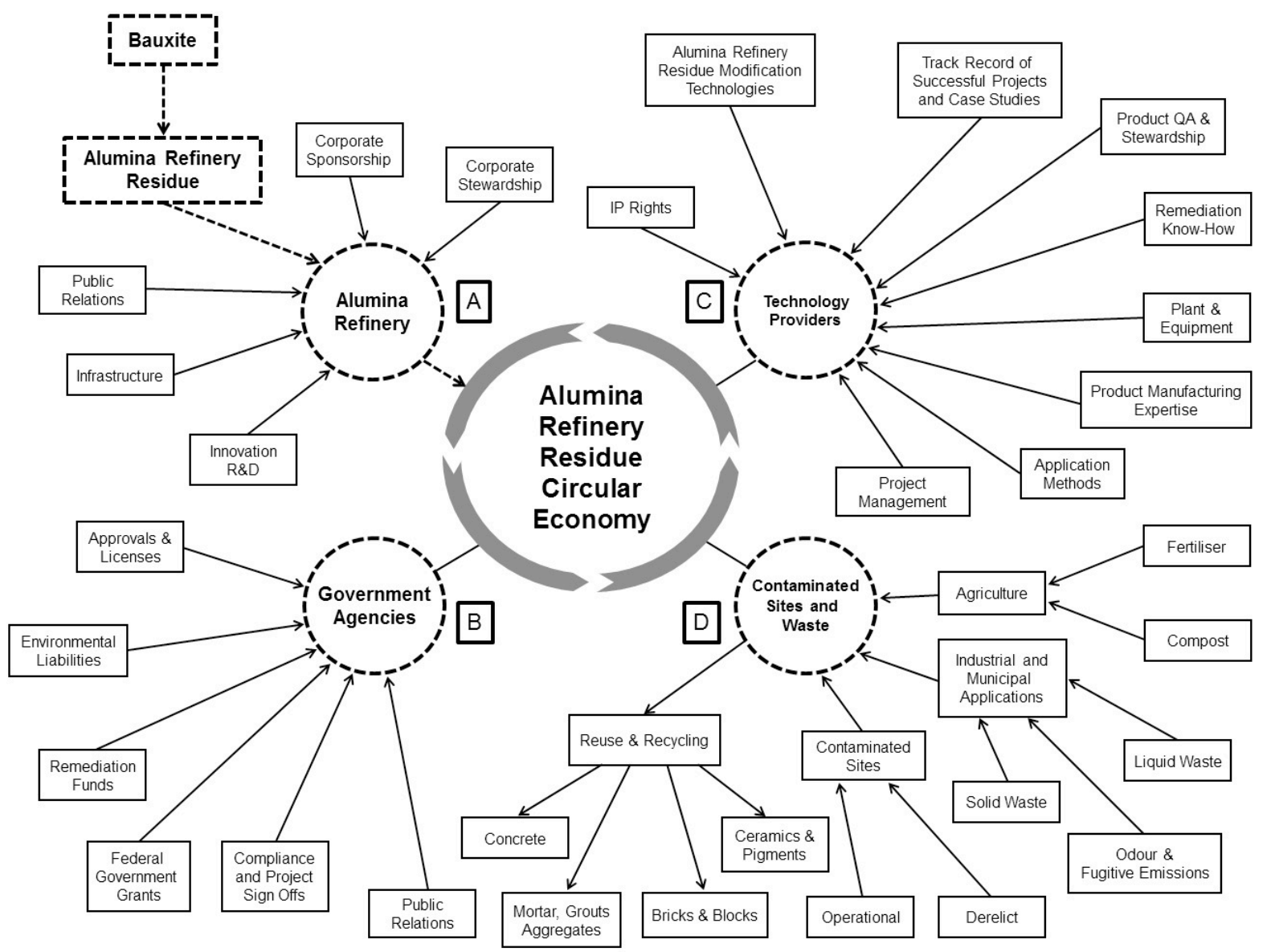

Figure 4. The CE model for repurposed ARR, stakeholders A-D.

The model assumes the third main contributors to the circular economy are innovative technology companies $[\mathrm{C}]$ who possess the modification technologies which can convert ARR into a benign, useable but not inert raw material. Contributions to a sustainable future from technology providers include technological know-how, manufacturing expertise related to ARR product development, as well as knowledge about chemical blending and product packaging and delivery, while the circular economic benefits include increased commercial opportunities and growth of business, and access to a wider range of environmental projects.

Finally, owners and/or managers of contaminated sites and waste producers [D] can benefit from the reuse of ARR through the effective treatment of a variety of gaseous, liquid and solid waste streams which are amendable to ARR recycling and/or reuse, thereby reducing short- and long-term liability and the ongoing risk of non-compliance and fines from environmental agencies and. Moreover, waste "cost centres" can become "profit centres" for owners of contaminated sites and waste producers; by repurposing ARR as a feedstock into other industrial products, such as concrete manufacture, bricks and blocks, ceramics, geopolymers, and mortars, grouts and aggregates, among other applications.

In Figure 5, contributions by socially responsible investors (SRIs) [E] to the ARR circular economy include the opportunity to invest in bankable, high-return 
environmentally and socially responsible investments in projects and companies, which make a difference to the welfare of society; SRIs benefit by securing a return on investment, enhancing their kudos and intellectual capital, and by participating in more socially and environmentally responsible investment opportunities. Similarly, the media $[\mathrm{F}]$ have a role to play in contributing to a circular economy. Its role is becoming increasingly recognised as a key element in sustainability assessments of corporate social responsibility (CSR).

Contributions by the media include factual, evidence-based and informative communication with the general public, government and industry on ARR reuse projects and other industrial reuse initiatives, as well as exchanges of information and opinion via online discussion forums and blogs. The media can benefit from a sustainable future by receiving information on sustainable development initiatives and environmental projects from industry, government and the general public, thereby enhancing their intellectual capital and credibility in society.

The scientific research community [G] can participate in the ARR circular economy by examining the merits and outcomes of sustainable development projects, and by accessing international, peer-reviewed journals and scientific and community projects and initiatives can better inform policy and decision-making. Benefits to the scientific research community include access to a wide variety of environmental projects at the leading edge of science and technology, data on the environment and sustainable development, and increased knowledge capital. Moreover, environmental consultants and engineers, industry associations and independent third parties, such as civil contractors $[H]$, can participation in projects by engineering and environmental experts, thereby significantly expanding their client and collegiate networks; certified laboratories can enhance their intellectual capital and client base, and transportation can contribute expertise in the bulk handling of materials and supply chain management (SCM). These types of stakeholders can benefit from increased employment and business opportunities, increased know-how and exposure to more projects, increased access to client and colleague networks through business synergies, and an expanded client and increased member base for industry organisations.

Finally, the general public [I] can contribute to and benefit from participation in an AAR circular economy. For example, contributions to a sustainable future from the general public include participation of non-government organisations (NGOs), environmentalists, concerned citizens and community action groups, and enlightenment of the public will through community forums, workshops and town hall meetings, while increased access to useful public sites which had previously been of no value or a liability to society, reduced long-term environmental and government liability, greater employment opportunities, and improved educational opportunities and increased knowledge about the environment are among the likely beneficial outcomes. In these ways, it becomes evident that an ARR circular economy can beneficially touch a great many social, commercial and government sectors, enhancing each in ways which have yet to be fully explored or understood, including potential impacts on public health. 


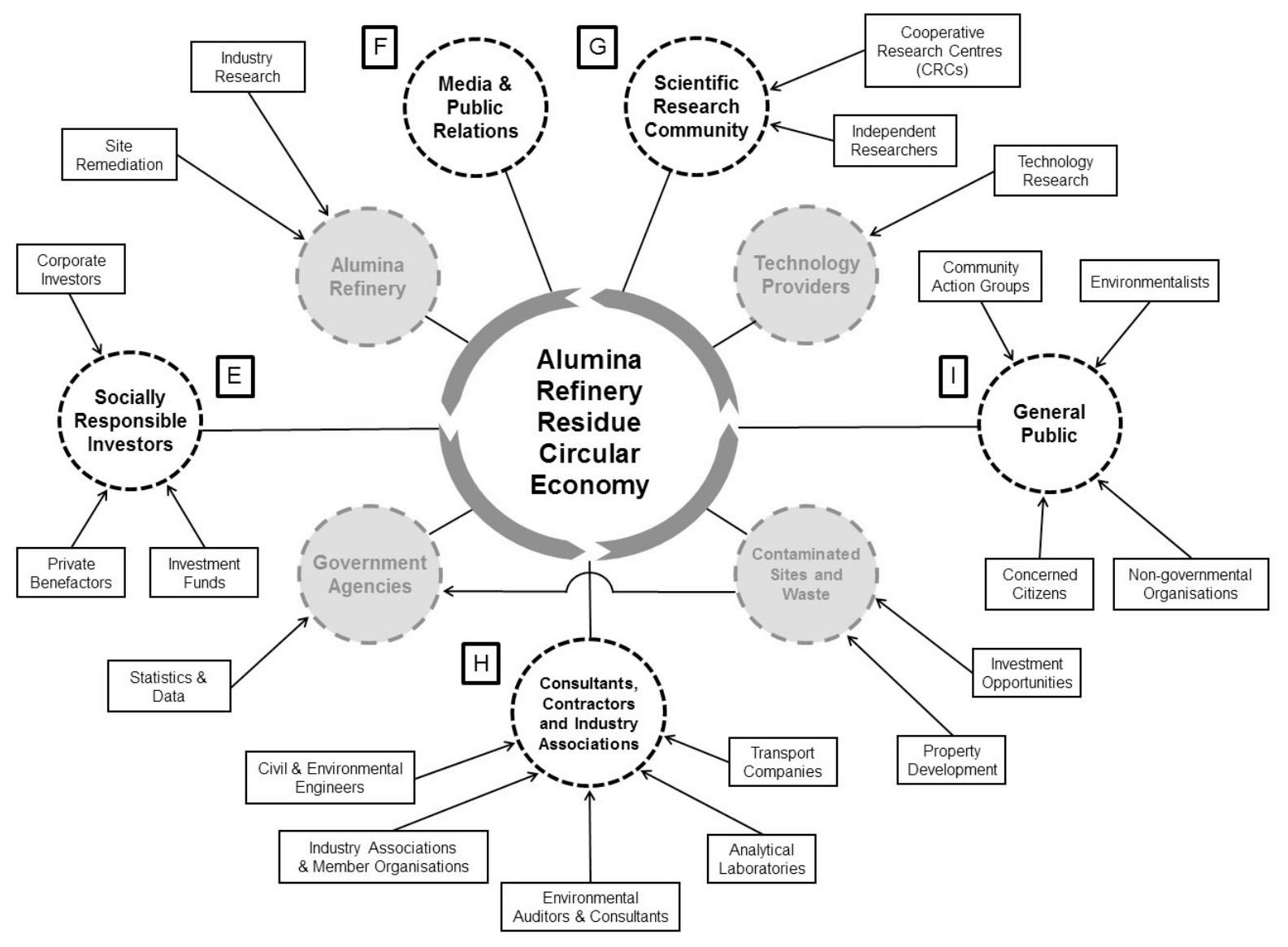

Figure 5. The CE model for repurposed ARR, stakeholders E-I.

There are also a wide variety of industries and applications, which can benefit from repurposed ARR, mostly by remediating industrial sites or other forms of gaseous, liquid or solid wastes. In some cases, these industries and applications can generate other reusable and saleable products. Industries and applications which can benefit (and have benefited) from ARR include: agriculture and horticulture; concrete manufacture and speciality cementitious product manufacture; sewerage treatment plants (STPs); composting facilities; landfill operations; mine sites and industries, such as lead and zinc smelters, gas works, timber preservation companies, quarries, manufacturing companies, and electroplating companies; dredging and land reclamation operations; coal seam gas (CSG) and underground coal gasification (UCG) operations and other oil and gas operations; bio-refineries; property developers; coal-fired power plants; and steel plants, among many others (e.g., Fergusson 2009, 2016a; Klauber, et al., 2009).

Figure 6 presents an example of six industries labelled [A] to [F], which have benefited from the application of repurposed ARR, and shows the potential interactions or synergistic loops which can be identified between them. Each of these applications have been well-documented in the available literature. Specifically, Figure 6 suggests how waste streams amended with repurposed ARR in one industry (i.e., an output) can be reapplied as an input for beneficial reuse in another industry, thereby creating a $\mathrm{CE}$ which mimics the self-referral structure of Natural Law. Figure 6 also presents the logical endpoint of such an 
economic approach to ARR by showing the documented net gain to society or industry of the application in the outer circles of the diagram.

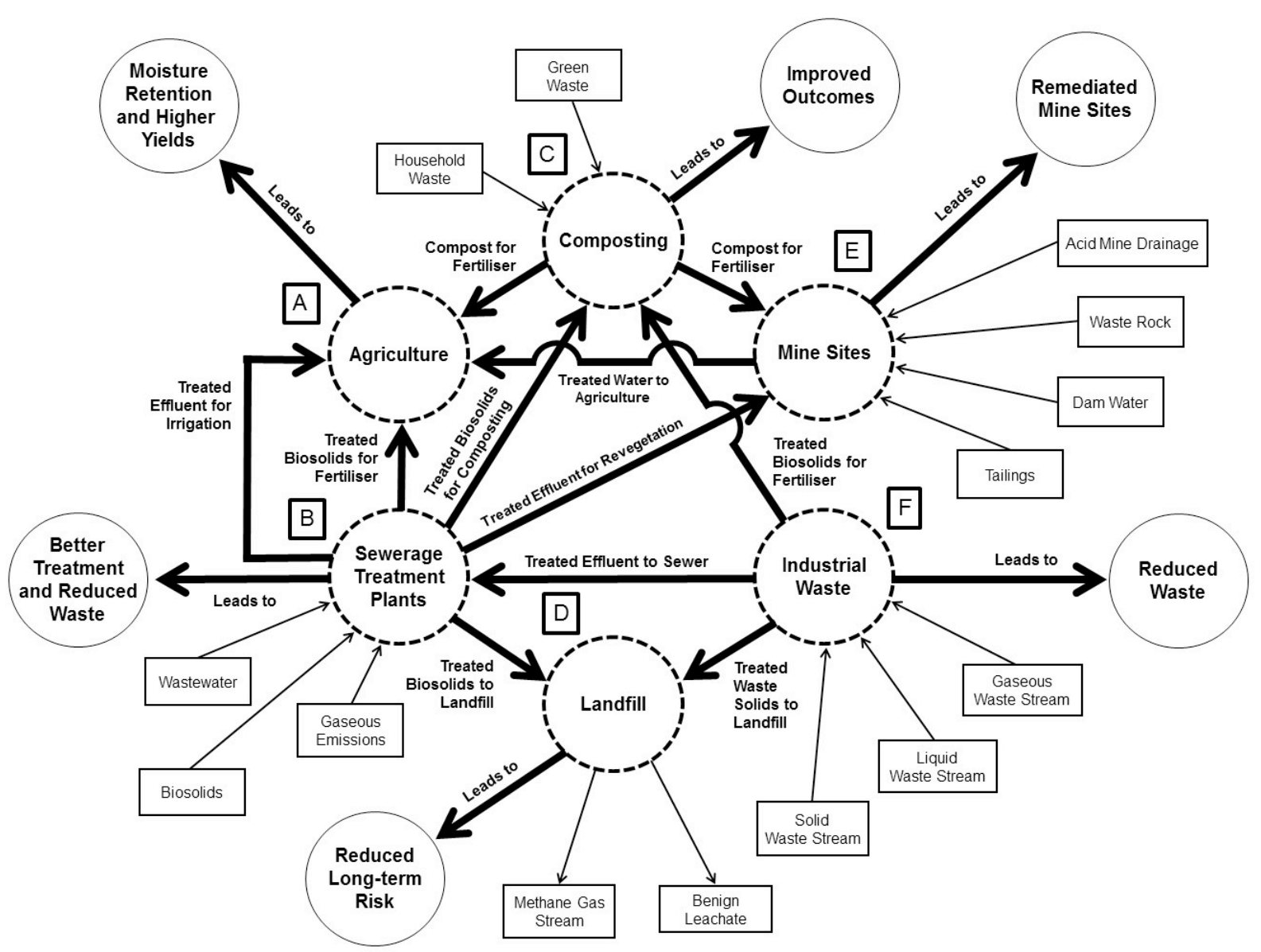

Figure 6. Beneficial reuse potentials across six industries [A-F] when considering treated waste after addition of modified ARR, how the waste can be reused by another industry, and what sustainability outcomes can be expected for each industry and application.

For example, when applied to agriculture [A], repurposed ARR has been shown to help soil retain moisture, help soil retain phosphate (a valuable nutrient) in a bio available form, promote plant growth, help soil sequester heavy metals which may be damaging to plants and trees, which together lead to higher crop yields (Fergusson, 2016b). Similarly, when repurposed ARR is added to green and household putrescible waste used in composting [C] by municipal councils, the application results in higher composting temperatures, more rapid degradation of compost, and a higher quality compost (e.g., Waddell, et al., 2002). Compost [C] amended with ARR can then also be used as a fertiliser in both agriculture $(\mathrm{A})$ and in mine site revegetation $[\mathrm{E}]$.

There are a variety of gaseous, liquid and solid waste streams generated at mine sites [E], including waste rock, tailings, wastewater, and fugitive sulfur emissions, which can be directly amended with repurposed ARR or with ARRamended compost [C] or STP waste [B], wastes which can themselves be amended with repurposed ARR (Fergusson, 2015b). Depending on the type of waste, amended mine site wastewater, including acid mine drainage (AMD), can 
be safely discharged to the local receiving environment, and mine sites can be remediated using repurposed ARR, a well-documented phenomenon. Such rehabilitation programs also promote grass and tree growth, including revegetation of derelict mine sites, resulting in remediated mine sites and a cleaner, more sustainable society and environment (e.g., Fergusson, 2014b). Given there are 160,000 such contaminated sites in Australia alone (University of Technology Sydney, 2014), attempts to circularise the use of re-purposed ARR seem noteworthy.

There are a wide variety of gaseous, liquid and solid waste streams from multiple industrial processes $[\mathrm{F}]$, many of which are amendable to treatment by repurposed ARR. For example, ARR-treated gaseous emissions do not result in greenhouse gas generation or pollution of the atmosphere (e.g., Hutson \& Attwood, 2008), and depending on the type and classification, some treated industrial wastewater $[\mathrm{F}]$ can be discharged to the sewer $[\mathrm{B}]$ as "trade waste". Some treated industrial solids can also be used in composting [C] or go to landfill [D] in a reclassified form (e.g., from hazardous to low-level leachable metals), thereby reducing the cost of solid waste disposal and long-term risks to the environment and society (e.g., Fergusson 2015c, 2015d).

Figure 6 also illustrates circular interactions between applications, further expanding the range of APR sustainability. For example, APR-amended sewage wastewater and/or biosolids can be reused to treat landfill fugitive gases and create benign leachate, in fertiliser and irrigation, composting and mine site revegetation, and APR-amended compost can be used as fertiliser in agriculture and at the mine sites. In each case, a longer term sustainability outcome can be realised, including more effective treatment and reduction of waste.

This type of self-interacting, circularity results in a general reduction of industrial waste volumes, as well a reduction in the problematic types of wastes, entering the environment, thereby achieving the ambitions of CE modeling. I would also argue that such an approach is more in accord with the principles of Natural Law than the aforementioned linear take, make, dispose mentality of the past, and would contribute to achieving the aspirations of a sustainable, circular economy.

\section{Conclusion}

I have established that the CE model represents a new and innovative way to conceive of industrial processes, practices, programs and systems, and such an approach is designed to achieve many of the broader goals of industrial sustainability. CE counters the rapaciousness of the linear economic model, which embraces 'development' at all costs, while often also leaving a legacy of waste stockpiles and global pollution for future generations to address. This is certainly the case with alumina refinery residue, which poses a significant long-term threat to humans, animals, ecologies and environments in which it is stored, and to the seas and oceans into which it is discharged.

Part I of this two-part series of papers located the foundations of CE in the self-referral feedback loops of Natural Law as identified by Maharishi, and showed that $\mathrm{CE}$ is a more sustainable approach to industrial minerals processing in the twentieth-first century, specifically in relation to alumina refinery residue, 
and I propose that by embracing the self-referral character of the function and structure of Natural Law industries throughout the world may contribute to a more sustainable future for humanity.

\section{Acknowledgement}

Figures 4-6 are modified diagrams which first appeared in Fergusson, L. (2014). A sustainability framework for the beneficial reuse of alumina refinery residue. Journal of Multidisciplinary Engineering Science and Technology, 1(5), 105-120, and later modified for India in Fergusson, L., \& Nandi, A. (2015). Sustainable Indian alumina refineries: Beneficiation and reuse of bauxite residue, Minerals \& Metals Review, XLI (5), 25-28.

\section{References:}

Ackom, E.K., Mabee, W.E., \& Saddler, J.N. (2010). Industrial sustainability of competing wood energy options in Canada. Applied Biochemistry and Biotechnology, 162, 2259-2272. doi: 10.1007/s12010-010-9000-6

Aluminium Association. (February 2000). The. Technology roadmap for bauxite residue treatment and utilization. Washington, D.C.: The Aluminium Association.

Aluminium Association. (February 2001). The. Aluminum industry vision: Sustainable solutions for a dynamic world. Washington, D.C.: The Aluminium Association.

Aluminium Association. (February 2003).Aluminum industry technology roadmap. Washington, D.C.: The Aluminium Association.

AMIRA International. (May 2006).Alumina technology roadmap. Melbourne, Australia: AMIRA International.

BBC News (2010). Hungarian chemical sludge spill reaches Danube.BBC News Europe, October 7 , 2010.

Bray, E.L. (2014). Bauxite and alumina. Reston, Virginia: U.S. Geological Society, Mineral Commodity Summaries.

Brunori, C. Cremisini, C., Massanisso, P., Pinto, V., \& Torricelli, L. (2005). Reuse of a treated red mud bauxite waste: Studies on environmental compatibility. Journal of Hazard Materials, 117(1), 55-63. doi: 10.1016/j.jhazmat.2004.09.010

Chertow, M.R. (2007). 'Uncovering' industrial symbiosis. Journal of Industrial Ecology, 11, 11-30. doi:10.1162/jiec.2007.1110

Chuan-Sheng, W., \& Dong-Yan, L. (2012). Mineral phase and physical properties of red mud calcined at different temperatures. Journal of Nanomaterials, Article ID 628592. doi: 10.1155/2012/628592

Ellen MacArthur Foundation. (2017). Urban biocycles. Isle of Wight: United Kingdom: Author.

Energetics Incorporated. (1996). Alumina technology roadmap. Columbia, Maryland: Energetics International.

European Aluminium Association. (2013). Bauxite residue management: Best practice. London, United Kingdom: International Aluminium Institute.

Fergusson, L. (in review). Industrial sustainability and the circular economy as counterparts to the self-referral structure of natural law: Part I-A theoretical foundation.

Fergusson, L. (2009). Commercialisation of environmental technologies derived from alumina refinery residues: A ten-year case history of Virotec. Commonwealth Scientific and Industrial Research Organisation (CSIRO), Project ATF-06-3 'Management of Bauxite Residues', Department of Resources, Energy and Tourism (DRET), Commonwealth Government of Australia, as part of the Asia-Pacific Partnership on Clean Development and Climate, Canberra, Australia.

Fergusson, L. (2014a). A sustainability framework for the beneficial reuse of alumina refinery residue. Journal of Multidisciplinary Engineering, Science and Technology, 1(5), 105-120.

Fergusson, L. (2014b). A long-term study of mine site contamination and rehabilitation in Australia. Asian Journal of Water, Environment and Pollution, 11(4), 1-17.

Fergusson, L. (2015a). Red mud futures: Repurposing one of the world's largest waste by-products. Saarbrücken, Germany: Lambert Academic Publishing. 
Fergusson, L. (2015b). A field trial using modified alumina refinery residue to beneficiate composting at a dairy farm in Saudi Arabia. International Journal of Agriculture Innovations and Research, $4(2), 396-407$.

Fergusson, L. (2015c). A field trial to engender micro-concentrations of lead(II) using a novel sorbent in highly acidic industrial wastewater at a smelter site in Derbyshire. International Journal of Multidisciplinary Research and Development, 2(9), 437-444.

Fergusson, L. (2015d). Three novel methods for removing inorganic species from contaminated industrial stormwater at a smelter site in London. Journal of Applied Research in Water and Wastewater, 2(1), 115-121.

Fergusson, L. (2016a). What a waste: Studies in anthropogenic sources of pollution. Saarbrücken, Germany: Lambert Academic Publishing.

Fergusson, L. (2016b). Advances in soil amendments: Vermicomposting, alumina refinery residue and cotton production in Australia. International Journal of Environment and Agricultural Research, 2016, 2(2), 1-11.

Fergusson, L.C., \& Bonshek, A.J. (eds.) (2015). The unmanifest canvas: Maharishi Mahesh Yogi on the arts, creativity and perception. Fairfield, Iowa: Maharishi University of Management Press.

Fergusson, L., Wells, G., \& Kettle, D. (2016). Principles and practice of sustainability in Maharishi Vedic Science. Journal of Health and Environmental Research, 3(3-1), 1-15.doi: 10.11648/j.jher.s.2017030301.11

Fergusson, L., Wells, G., \& Kettle, D. (2017a). The personal, social and environmental sustainability of Jainism in light of Maharishi Vedic Science. Environment, Development and Sustainability, 19, 1-23. doi: 10.1007/s10668-017-9957-1

Fergusson, L., Kettle, D., \& Wells, G. (2017b). Indigenous accounts of environmental stewardship in light of the theory and language of Maharishi Vedic Science. International Journal of Society, Culture 8 Language, 5(1), 68-81.

Fiscor, S. (2013). Cleaning up the red mud. Engineering and Mining Journal, July 25.

Gatti, C., \& Macchi, P. (eds.) (2012). Modern charge-density analysis. London and New York: Springer Science+Business Media.

Geng, Y., Zhu, Q., Doberstein, B., \& Fujita, T. (2009). Implementing China's circular economy concept at the regional level: A review of progress in Dalian, China. Waste Management, 29(2), 996-1002. doi: 10.1016/j.wasman.2008.06.036

George, D.A.R., Lin, B.C., \& Chen, Y. (2015). A circular economy model of economic growth. Environmental Modeling \& Software, 73, 6-63. doi: 10.1016/j.envsoft.2015.06.014

Ghisellini, P., Cialani, C., \& Ulgiati, S. (2016). A review on circular economy: The expected transition to a balanced interplay of environmental and economic systems. Journal of Cleaner Production, 114, 11-32. doi: 10.1016/j.jclepro.2015.09.007

Harris, M.A. (2016). Geobiotechnological solutions to anthropogenic disturbances: A Caribbean perspective. Switzerland: Springer.

Heaton, D. (2016). Higher consciousness for sustainability-as-flourishing. In S. Dhiman and J. Marques (eds.), Spirituality and Sustainability: New Horizons and Exemplary Approaches [pp. 121-137], Springer International Publishing, Switzerland.

Heisenberg, W. (1984).Introduction to the unified field theory of elementary particles. In W. Blum, H-P. Dürr, \& H. Rechenberg, (eds.), Scientific Review Papers, Talks, and Books, Volume B of the series "Gesammelte Werke/Collected Works" [pp. 677-861], Wissenschaftliche Übersichtsartikel, Vorträge und Bücher, Berlin and Heidelberg, Springer-Verlag.

Hutson, N.S., \& Attwood, B.C. (2008). Binding of vapour-phase mercury $\left(\mathrm{Hg}^{0}\right)$ on chemically treated bauxite residues (red mud). Environmental Chemistry, 5(4), 281-288. doi: 10.1071/EN08026

International Aluminium Institute. (2010a). Alumina technology roadmap, 2010 update. London: Bauxite and Alumina Committee, International Aluminium Institute.

International Aluminium Institute, (2010b). Global aluminium industry sustainability scorecard 2009. London: International Aluminium Institute.

Kettle, D., Wells, G., \& Fergusson, L. (2017). Human development and capability: Reconstructed and fulfilled through Maharishi Vedic Science. Journal of Health and Environmental Research, 3(3-1), 78-89.doi: 10.11648/j.jher.s.2017030301.16

Klauber, C., Gräfe, M., \& Power, G. (2009). Review of bauxite residue "re-use" options. Commonwealth Scientific and Industrial Research Organisation (CSIRO), Project ATF-06-3 "Management of Bauxite Residues", Department of Resources, Energy and Tourism (DRET), Commonwealth Government of Australia, Asia-Pacific Partnership on Clean Development and Climate, Canberra, Australia. 
Jambeck, J.R., Geyer, R., Wilcox, C., Siegler, T.R., Perryman, M., Andrady, A., Narayan, R., \&Law, K.L. (2015). Plastic waste inputs from land into the ocean. Science, 347(6223), 768-771.doi: 10.1126 /science.1260352

Jiang, Y., Marang, L., Tamis, J., van Loosdrecht, M.C.M., Dijkman, H., \& Kleerebezem, R. (2012). Waste to resource: Converting paper mill wastewater to bioplastic. Water Research, 46, 55175530. doi: 10.1016/j.watres.2012.07.028

Lacy, P., \& Rutqvist, J. (2015). Waste to wealth: The circular economy advantage. London: Palgrave Macmillan.

Maharishi Global Development Fund. (1998). Maharishi Global Development Fund: Creating a better quality of life. India: Age of Enlightenment Publications.

Maharishi Mahesh Yogi. (1986). Life supported by natural law: Lectures by His Holiness Maharishi Mahesh Yogi. Washington, D.C.: Age of Enlightenment Press.

Maharishi Mahesh Yogi. (1991). Maharishi's master plan to create heaven on earth. Holland: Maharishi Vedic University Press.

Maharishi Mahesh Yogi. (1994). Maharishi Vedic University: Introduction. India: Maharishi Ved Vigyān Vishwa Vidyā Peetham.

Maharishi Mahesh Yogi. (1995). Maharishi's absolute theory of government. Holland: Maharishi Vedic University Press.

Maharishi Mahesh Yogi. (1996a). Maharishi's absolute theory of defence: Sovereignty in invincibility. India: Maharishi Vedic University.

Maharishi Mahesh Yogi. (1996b). Inaugurating Maharishi Vedic University. India: Maharishi Vedic Vishwavidyalaya Press.

MaharishiMaheshYogi.(1996c).Maharishi forum of natural law and national law for doctors. India: Maharishi Vedic University Press.

Maharishi Mahesh Yogi. (1998). Celebrating perfection in administration: Creating invincible India. India: Maharishi Vedic University Press.

Mathews, J.A., \& Tan, H. (2011). Progress toward a circular economy in China: The drivers (and inhibitors) of eco-industrial initiative. Journal of Industrial Ecology, 15(3), 435-457. doi: 10.1111/j.1530-9290.2011.00332.x

Mayes, W.M., Burke, I.T., Gomes, H.I., Anton, Á.D., Molnár, M., Feigl, V., \& Ujaczki, É. (2016). Advances in understanding environmental risks of red mud after the Ajka spill, Hungary. Journal of Sustainable Metallurgy, 2(4), 332-343. doi: 10.1007/s40831-016-0050-z

Pollard, S., Turney, A., Charnley, F., \& Webster, K. (2016). The circular economy: A reappraisal of the stuff we 'love'. Geography, 101(1), 17-27.

Power, G., Gräfe, M., \&Klauber, C. (2009). Management of bauxite residue: Priority research areas. Commonwealth Scientific and Industrial Research Organisation (CSIRO) document DMR-3611, part of Project ATF-06-3 'Management of Bauxite Residues', Department of Resources, Energy and Tourism (DRET), Commonwealth Government of Australia, Asia-Pacific Partnership on Clean Development and Climate, Canberra, Australia.

Power, G., Gräfe, M.,\& Klauber, C. (2011). Bauxite residue issues: I. Current management, disposal and storage practices. Hydrometallurgy, 108(1), 33-45. doi: 10.1016/j.hydromet.2011.02.006

Probert, A. (2014). Bauxite: Will Australia fill Indonesia's shoes? Australian Journal of Mining, May 7 .

Rai, S., Wasewar, K.L., Mukhopadhyay, J., Yoo, C.K., \& Uslu, H. (2012). Neutralization and utilization of red mud for its better waste management. Archives of Environmental Science, 6, 1333.

Schmitz, C. (ed. (2006). Handbook of aluminium recycling. Germany: Vulcan/Verlag.

Solow, R.M. (2014). An almost practical step toward sustainability. New York: Routledge.

Stahel, W.R. (2016). Circular economy. Nature, 532, 435-438.

Su, B., Heshmati, A., Geng, Y., \& Yu, X. (2013). A review of the circular economy in China: Moving from rhetoric to implementation. Journal of Cleaner Production, 42, 215-227. doi: 10.1016/j.jclepro.2012.11.020

Tietenberg, T., \& Lewis, L. (2016). Environmental and natural resource economics (tenth edition). New York: Routledge.

Tillman, D., Wedin, D., \& Knops, J. (1996). Productivity and sustainability influenced by biodiversity in grassland ecosystems. Nature, 379, 718-720. doi:10.1038/379718a0

Tisserant, A., Pauliuk, S., Merciai, S., Schmidt, J., Fry, J., Wood, R., \& Tukker, A. (2017). Solid waste and the circular economy: A global analysis of waste treatment and waste footprints. Journal of Industrial Ecology, 21(3), 628-640. doi: 10.1111/jiec.12562 
Tonelli, F., Evans, S., \& Taticchi, P. (2013). Industrial sustainability: Challenges, perspectives, action. International Journal of Business Innovation and Research, 7(2), 143-163. doi: 10.1504/IJBIR.2013.052576

Tukker, A. (2015). Product services for a resource-efficient and circular economy-A review. Journal of Cleaner Production, 97, 76-91. doi: 10.1016/j.jclepro.2013.11.049

University of Technology Sydney. (2014). Contaminated soil wastes in Australia. Sydney, NSW: Institute for Sustainable Futures, University of Technology Sydney.

Yuan, Z., Bi, J., \& Moriguichi, Y. (2006). The circular economy: A new development strategy in China. Journal of Industrial Ecology, 10(1-2), 4-8. doi: 10.1162/108819806775545321

Waddell, B., Mann, S., \& Allen, D. (November, 2002). Improvement of soil quality by waste amendment. Perth, Western Australia: Chemistry Centre.

Webster, K. (2017). The circular economy: A wealth of flows (2nd edition). Isle of Wight, United Kingdom: Ellen MacArthur Foundation.

Wells, G. (ed.) (2013). Sustainable business: Theory and practice of business under sustainability principles. Cheltenham, United Kingdom and Northampton, Massachusetts: Edward Elgar.

Wells, G., Fergusson, L., Kettle, D., \& Bonshek, A. (2017). Responding to climate change: The contribution of Maharishi Vedic Science. Journal of Health and Environmental Research, 3(3-1), 63-78. doi: 10.11648/j.jher.s.2017030301.15

Withers, P.J.A., van Dijk, K.C., Neset, T-S.S., Nesme, T. Oenema, O., Rubæk, G.H., Schoumans, O.F., Smit, B., \&Pellerin, S. (2015). Stewardship to tackle global phosphorus inefficiency: The case of Europe. AMBIO, 44(Suppl. 2), S193-S206. doi: 10.1007/s13280-014-0614-8

Zhang, H., Hara, K., Yabar, H., Yamaguchi, Y., Uwasu, M., \& Morioka, T. (2009). Comparative analysis of socio-economic and environmental performances for Chinese EIPs: Case studies in Baotou, Suzhou, and Shanghai. Sustainability Science, 4, 263-279. doi: 10.1007/s11625-009-0078-0

Zhu, Q., Geng, Y., \& Lai, K-h. (2010). Circular economy practices among Chinese manufacturers varying in environment-oriented supply-chain cooperation and performance indications. Journal of Environmental Management, 91, 1324-1331. doi: 10.1016/j.jenvman.2010.02.013 